\title{
Carcinomatous degeneration of pilonidal cyst with sacrum destruction and invasion of the rectum ${ }^{*}$ \\ Degeneração carcinomatosa do cisto pilonidal com destruição do sacro e invasão da parede do reto
}

\author{
Luiz Fernando Nunes ${ }^{1}$ \\ Roberto André Torres Vasconcelos ${ }^{3}$ \\ Juliana Castilho ${ }^{4}$ \\ Washington Silva Noguera ${ }^{6}$
}

\author{
Antonio Kneipp Pitta de Castro Neto ${ }^{2}$ \\ Flávio Cajaraville ${ }^{4}$ \\ José Francisco Netto Rezende ${ }^{5}$
}

DOI: $h$ ttp://dx.doi.org/10.1590/abd1806-4841.20132140

\begin{abstract}
Malignant degeneration of pilonidal cysts is rare. The most common histologic type is the squamous cell carcinoma, triggered by the chronic inflammatory process. The growth of the lesion is typically slow. The diagnosis must be early and the appropriate treatment is ample surgical resection, including the presacral fascia. In some cases, as the present one, the diagnosis is made at a stage when the disease has progressed and invaded adjacent structures. In these cases the surgery involves multiple organ resection. We report the case of a patient with carcinomatous degeneration of pilonidal cyst, with bulky disease that extended up to the wall of the rectum. The treatment was extended resection, sacrectomy and abominoperineal resection of the rectosigmoid with permanent colostomy.

Keywords: Carcinoma, squamous cell; Neoplasms, squamous cell; Pilonidal sinus; Skin

Resumo: A degeneração maligna do cisto pilonidal é rara. O tipo histológico mais freqüente é o carcinoma epidermóide e tem como fator desencadeante o processo inflamatório crônico. O tumor é de crescimento lento. O diagnóstico deve ser precoce e o tratamento cirúrgico adequado é a ressecção ampla incluindo a fáscia pré-sacral. Em alguns casos, como o que apresentamos, o diagnóstico é feito numa fase em que a doença progrediu e invadiu as estruturas adjacentes. Nestes a cirurgia necessária envolve a ressecção multiorgânica. Apresentamos paciente com degeneração carcinomatosa do cisto pilonidal, com doença volumosa que se estendia até a parede do reto. O tratamento realizado foi ressecção alargada, sacralectomia e ressecção abominoperineal do retossigmóide com colostomia definitiva.

Palavras-chave: Carcinoma de células escamosas; Neoplasias de células escamosas; Pele; Seio pilonidal
\end{abstract}

\section{INTRODUCTION}

Carcinomatous degeneration of pilonidal cysts is rare. The incidence of this condition is estimated at $0.1 \%$ and is triggered by the chronic inflammatory process. ${ }^{1}$ When not treated early the injury may progress and invade adjacent structures. Proper treatment is surgery with tumor resection when necessary. It may involve multiple organ resection because of the extent of the injury. The objective of this report is to present the case of a patient with locally advanced squamous cell carcinoma secondary to chronic inflammation of a pilonidal cyst invading the sacrum and the mesorectum, the muscular wall of the rectum, conduct a literature review and discuss the treatment.

Received on 19.09.2012.

Approved by the Advisory Board and accepted for publication on 01.02.2013.

* Work performed at the Soft Tissue and Skin Cancer Department - National Cancer Institute (INCA) - Rio de Janeiro (RJ), Brazil.

Financial Support: none

Conflict of Interests: none

MD, Specialist in skin and soft tissue tumors. Oncology Surgeon - Soft Tissue and Skin Cancer Department - National Cancer Institute (INCA) - Rio de Janeiro - Brazil.

MD, Oncology Surgeon - Soft Tissue and Skin Cancer Department - National Cancer Institute (INCA) - Rio de Janeiro - Brazil.

MD, Oncology Orthopedist - Soft Tissue and Skin Cancer Department - National Cancer Institute (INCA) - Rio de Janeiro - Brazil.

MD, Oncology Surgeon Resident - National Cancer Institute (INCA) - Rio de Janeiro (RJ), Brazil.

MD, Oncology Surgeon - Soft Tissue and Skin Cancer Department Chairman - National Cancer Institute (INCA) - Rio de Janeiro - Brazil.

Pathologist Staff - National Cancer Institute (INCA) - Rio de Janeiro (RJ), Brazil. 


\section{CASE REPORT}

Male patient, 61 years of age, with a history of treatment of chronic inflammatory process in the sacral region, resulting from a pilonidal cyst that had developed for ten years and never fully healed. It presented with ulcerated lesion affecting the entire sacrococcygeal region, extending to the buttocks and later progressing to two centimeters away from the anal margin. The lesion measured 22x17 cm, was crisp and full of bleeding fistulas with purulent discharge (Figure 1). We noted bulging of the posterior wall of the rectum without mucosal invasion. The inguinal lymph nodes were free of disease at clinical examination. The incisional biopsy report was well-differentiated squamous cell carcinoma (Figure 2). A sigmoidoscopy revealed a discrete area suggestive of extrinsic compression of the rectum, apparently without mucosal involvement at the level of the rectosigmoid junction. Magnetic resonance imaging of the abdomen demonstrated a large infiltrative and expansive formation presenting heterogeneous signal, hypointense on $\mathrm{T} 1$ and slightly hyperintense on $\mathrm{T} 2$, affecting the gluteal region, especially on the right side, where it invaded the muscles and ischiorectal fossa, determining coccyx bone destruction and infiltrating until the level of the last sacral pieces (Figure 3). The tumor also extended and previously affected the mesorectal fat and posterior wall of the rectum / lower rectum. Laboratory tests on admission showed anemia with hemoglobin of $3.16 \mathrm{~g} \mathrm{/} \mathrm{dl}$ and hematocrit of $10.50 \%$, albumin $2.1 \mathrm{~g} / \mathrm{dl}$ and leukocytosis with WBC count of 15,900 per $\mathrm{ml}, 86.97 \%$ segmented. The surgical approach started in the abdomen, with the patient supine. Initially a bilateral hypogastric artery ligation was performed as preparation for the abdominoperineal resection of the rectum cavity, with synthesis and maturation of permanent colostomy. Later the patient was placed in prone jackknife position, with en bloc resection of the lesion being carried out, including cutaneous lesions, sacral parts 3,4 and 5 and total mesorectal excision (Figures 4-6).

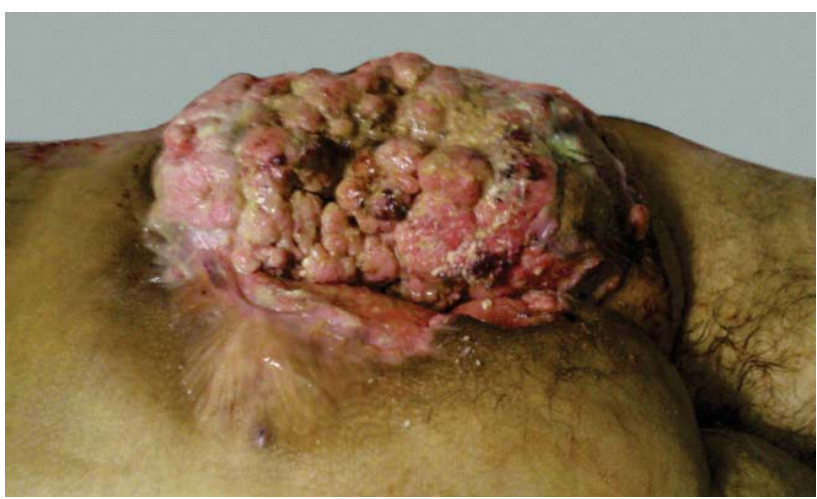

Figure 1: Extensive Sacral Squamous Cell Carcinoma

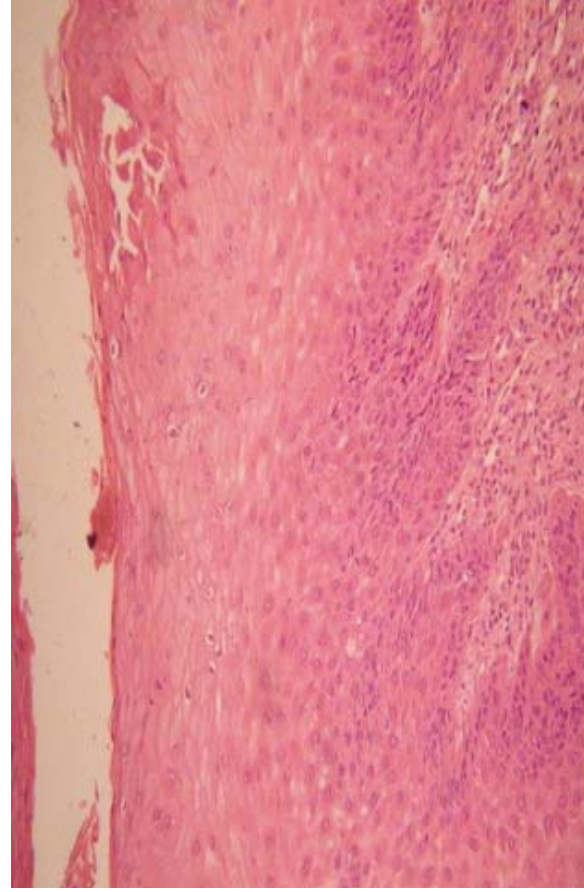

FIGURE 2:

Microscopic

view of

Squamous Cell

Carcinoma

(x100)

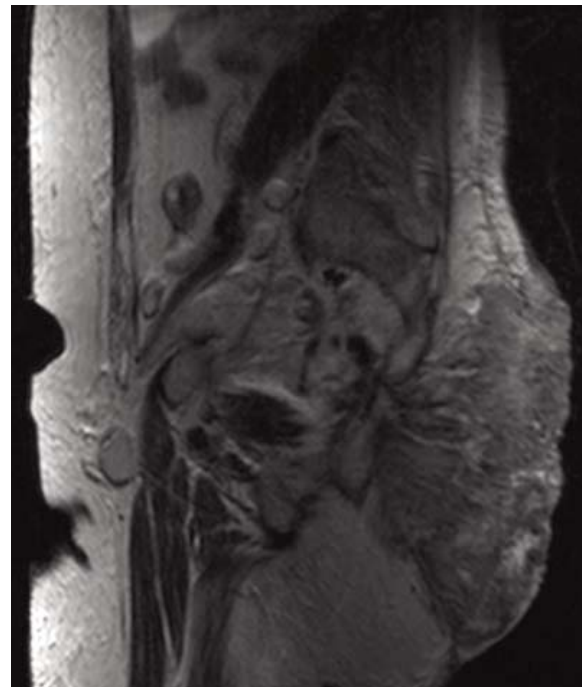

FiguRE 3:

Sacral Magnetic

Resonance

Imaging shows posterior wall of rectus invaded by Skin

Squamous Cell Carcinoma

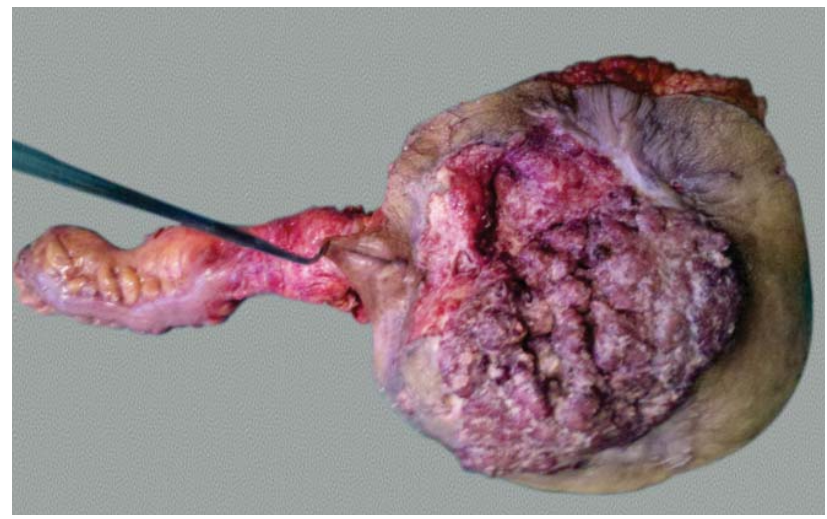

FIGURE 4: Monoblock sacral tumor, sigmoid, rectum e anus (anterior view) 


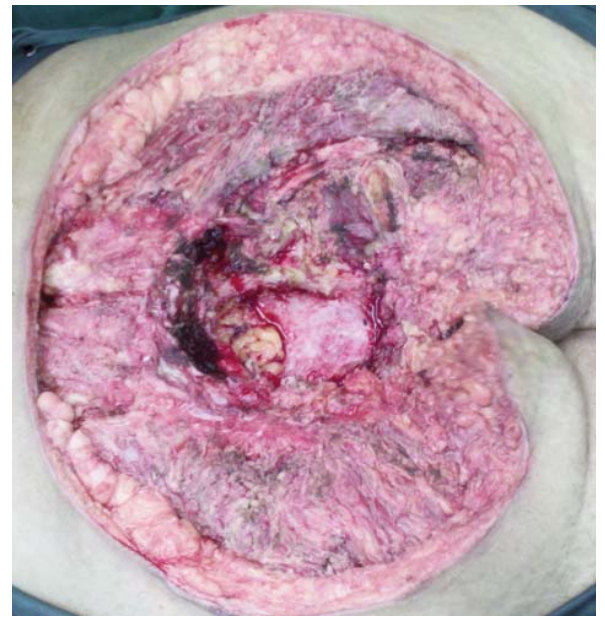

FIGURE 5:

Immediate sacral bloody defect after surgery

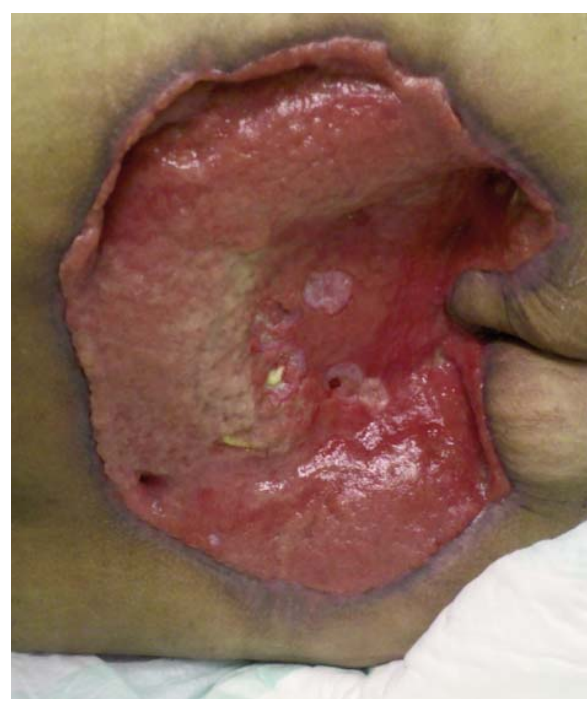

Figure 6: Late defect after the third month. Reduced bloody defect with granulation tissue

\section{DISCUSSION}

First described by Wolf, the malignant degeneration of pilonidal cyst is a rare disease and occurs in approximately $0.1 \%$ of pilonidal cyst cases. ${ }^{1}$ The most common histologic type is squamous cell carcinoma, occurring in approximately $88 \%$ of cases. ${ }^{1,2}$ Pilonidal cysts arise in the sacrococcygeal region near the anus. The most common complications are related to infectious processes as local cellulitis, abscess formation and recurrence. They rarely evolve with osteomyelitis and meningitis., ${ }^{3,4}$ The mechanism by which malignant degeneration appears in pilonidal cyst is probably related to chronic inflammatory processes, such as skin ulcers and fistulas.

The diagnosis of malignant degeneration of pilonidal cyst, although rare, should always be considered so that the process is carried out at an earlier stage, when less mutilating surgery is necessary. The preoperative evaluation should include examination of the rectum through lower endoscopy (sigmoidoscopy or colonoscopy). ${ }^{5}$ In the case described sigmoidoscopy was performed and identified extrinsic bulging of the rectum without mucosal involvement. The evaluation of the local extent of disease should be done with imaging tests (MRI or CT scan of the pelvis) to exclude osteomyelitis or bone invasion. In this case we chose MRI which showed invasion of the sacrum, mesorectal fat and posterior wall of the rectum. Staging was performed with computed tomography of the chest, abdomen and pelvis, showing no distant metastasis.

The treatment of choice remains the enlarged bloc resection with inclusion of the presacral fascia and frozen free margins..$^{6-8}$ In our case, considering the extent of the lesion with involvement of adjacent structures, sacral resection of the last pieces of the mesorectum and rectosigmoid was necessary for local control of the lesion. The local treatment with surgery has extended disease-free survival at 5 years to $61 \%$. The local recurrence rate is $42 \%$ and often occurs in the first year after surgery. ${ }^{3}$ In the cases considered inoperable Almeida Gonçalves, JC, presented a series of 7 cases of squamous cell carcinoma which were treated with liquid nitrogen cryotherapy, with complete response in $100 \%$ of cases. ${ }^{9}$

The prophylactic lymphadenectomy has not been recommended. The incidence of lymph nodes is $22 \%$ and of these $14 \%$ had lymph node metastasis. ${ }^{3}$ The series are so small and insufficient to determine whether prophylactic lymphadenectomy can impact the increased survival of patients with occult metastases.

The closure of the defect can be accomplished through the gluteal flap in VY, vascularized rectus abdominis flap or graft. ${ }^{10}$ In our case, we chose to leave the wound open to heal by $2^{\text {nd }}$ intention due to the extensive defect, the onset of an infectious process and hemodynamic instability. 


\section{REFERENCES}

1. Wolff H. Carcinom auf dem boden des dermoids. Arch Klin Chir. 1900;62:731-8.

2. Lerner HJ, Deitrick G. Squamous cell carcinoma of the pilonidal sinus: Report of a case and review of the literature. J Surg Oncol. 1979; 11:177-83.

3. Pilipshen SJ, Gray G, Goldsmith E, Dineen P. Carcinoma arising in pilonidal sinuses. Ann Surg. 1981;193:506-12.

4. Jamieson NV, Goode TB. Squamous cell carcinoma arising in a pilonidal sinus presenting with the formation of an abscess. Postgrad Med J. 1982;58:720-1.

5. Hoover EL, Marrero R, Bumpers H, Coles M, Parsh S, Doerr R. Surgical management of advanced squamous cell skin cancers. J Natl Med Assoc. 1993;85:912-5

6. Velitchklov N, Vezdarova M, Losanoff J, Kjossev K, Katrov E. A fatal case of carcinoma arising from a pilonidal sinus tract. Ulster Med J. 2001;70:61-3.

7. Chatzis I, Noussios G, Katsourakis A, Chatzitheoklitos E. Squamous cell carcinoma related to long standing pilonidal-disease. Eur J Dermatol. 2009;19:408-9.

8. De Martino C, Martino A, Cuccuru A, Pisapia A, Fatigati G. Squamous-cell carcinoma and pilonidal sinus disease. Case report and review of literature. Ann Ital Chir. 2011;82:511-4.

9. Almeida-Gonçalves JC. A curative cryosurgical technique for advanced cancer of sacrococcygeal pilonidal sinuses. J Surg Oncol. 2012;106:504-8.

10. Pandey MK, Gupta P, Khanna AK. Squamous cell carcinoma arising from pilonidal sinus. Int Wound J. 2012 doi: 10.1111/j.1742-481X.2012.01096.x.

\author{
MAILING ADDRESS: \\ Luiz Fernando Nunes \\ Rua Equador, 831 - Santo Cristo \\ 20220-410 - Rio de Janeiro - RJ \\ Brazil \\ E-mail:lfernandonunes@gmail.com
}

How to cite this article: Nunes LF, Keipp A, Vasconcelos RAT, Cajaraville F, Castilho J, Rezende JFN, Noguera WS. Carcinomatous degeneration of pilonidal cyst with sacrum destruction and invasion of the rectum. An Bras Dermatol. 2013;88(6 Suppl 1):S59-62. 